\title{
An improved method to culture Staphylococcus aureus from bovine milk
}

\author{
K. Artursson, ${ }^{* 1}$ M. Nilsson-Öst, ${ }^{*}$ and K. Persson Waller ${ }^{*} \dagger$ \\ *National Veterinary Institute, SE-751 89 Uppsala, Sweden \\ †Department of Clinical Sciences, Swedish University of Agricultural Sciences, SE-75007 Uppsala, Sweden
}

\begin{abstract}
Staphylococcus aureus is an important udder pathogen often associated with subclinical mastitis in dairy cows. Identification of Staph. aureus-positive udder quarters and cows is an important part of control programs to reduce spread of Staph. aureus within and between dairy herds. Therefore, accurate and easy-toperform culturing methods of Staph. aureus in milk are needed. In the present study, 8 methods for isolation of Staph. aureus in bovine milk samples were investigated. The methods involved different culturing volumes, enrichment, incubation, and freezing processes as well as sedimentation and use of the Mastistrip cassette (SVA, Uppsala, Sweden). Three different sets of milk samples were collected, and 6, 5, and 4 methods were used in each subset of samples. Our results indicate an increased probability of detecting Staph. aureus in milk samples when a simple incubation step $\left(37^{\circ} \mathrm{C}\right.$ for $18 \mathrm{~h}$ ) without additives was included before culturing. Using this incubation method, the number of Staph. aureus-positive udder quarters and cows increased by 50 and $29 \%$, respectively, compared with using the standard method of direct culturing of $10 \mu \mathrm{L}$ of milk. The improved method may be especially useful for detection of low concentrations of Staph. aureus in milk; for example, when screening herds for Staph. aureus.
\end{abstract}

Key words: Staphylococcus aureus, bacteriological culturing, bovine mastitis, milk samples

\section{INTRODUCTION}

Mastitis has a great economic impact on dairy production (Kossaibati and Esslemont, 1997; Østergaard et al., 2005) and is a matter of concern with respect to animal welfare and the use of antibiotics. To control mastitis in dairy herds, various udder health programs are used. For those programs, reliable information on SCC and the presence of udder pathogens is needed at both the herd and cow levels. Identification of infected cows is especially important to reduce spread

Received July 3, 2009.

Accepted December 17, 2009.

${ }^{1}$ Corresponding author: karin.artursson@sva.se of contagious pathogens such as Staphylococcus aureus. Infection with Staph. aureus often results in chronic subclinical mastitis, and Staph. aureus is the most commonly isolated udder pathogen in subclinical mastitis in Swedish dairy cows (Swedish Dairy Association, 2008). The cure rate after treatment with antibiotics is poor (Barkema et al., 2006) making Staph. aureus mastitis one of the most frequent reasons for culling of dairy cows. Moreover, many questions remain unanswered regarding the epidemiology of Staph. aureus mastitis.

Infected cows and quarters are normally identified through bacteriological examination of milk samples. A common strategy to identify Staph. aureus-positive udder quarters is to sample cows with elevated SCC, but it is not uncommon that bacteria are not detected in such samples. One reason for this is that the concentration of bacteria in milk of an infected quarter is not static and infected quarters may show a sinusoidal shedding pattern as shown by bacteriological culturing and real-time quantitative PCR (Sears et al., 1990; Daley et al., 1991; Studer et al., 2008). To increase the probability of detecting Staph. aureus in a single milk sample, various methods involving, for example, preenrichment in broth, centrifugation and culturing of sediment, culturing of larger volumes of milk, or freezing have been tested with varying results (Dinsmore et al., 1992; Zecconi et al., 1997; Sol et al., 2002). Recently, promising results have been obtained with methods based on PCR techniques (e.g., Graber et al., 2007; Studer et al., 2008; Taponen et al., 2009), but most routine laboratories still use bacteriological culturing as the primary method to isolate Staph. aureus.

In routine bacteriological diagnostics of Staph. aureus in milk samples from dairy cows, improved culturing methods that are sensitive and easy to perform are still needed. The aim of the present study was to compare 8 processing techniques, some previously tested and some new, for the isolation of Staph. aureus in bovine milk.

\section{MATERIALS AND METHODS}

\section{Milk Sampling}

Three sets of milk samples were collected and analyzed bacteriologically using different methods. In the 
Table 1. Numbers (\% of total number of Staphylococcus aureus-positive samples given in parentheses) of bovine udder quarter milk samples from which Staph. aureus was isolated using different sample processing methods

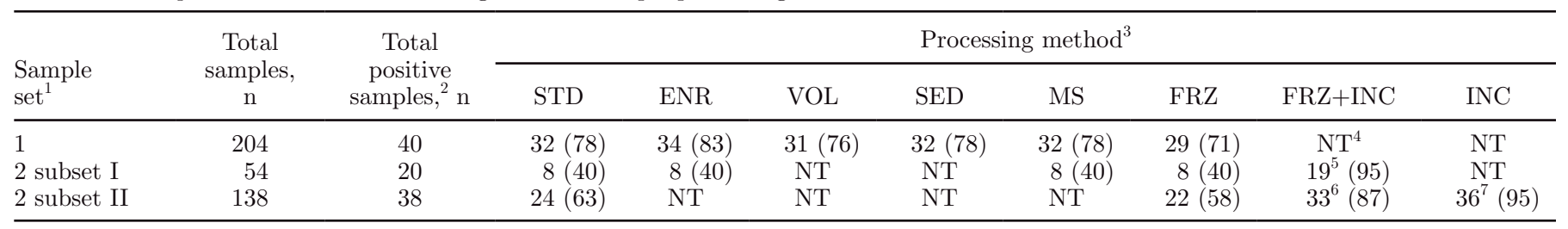

${ }^{1}$ Sample set 1 consists of milk samples from udder quarters with diagnosed subclinical mastitis in 200 cows. Sample set 2 includes milk samples from all udder quarters of cows having at least one udder quarter that had been culture positive for Staph. aureus within the last 2 mo. Different combinations of methods were applied for samples in subsets I and II.

${ }^{2}$ Number of samples positive with at least one method.

${ }^{3} \mathrm{STD}=$ standard method; ENR = enrichment method; VOL = larger volume method; SED = sedimentation method; MS = Mastistrip method; $\mathrm{FRZ}=$ freezing method; FRZ $+\mathrm{INC}=$ freezing and incubation method; INC $=$ incubation method.

${ }^{4} \mathrm{NT}=$ not tested.

${ }^{5}$ Statistically different $(P<0.001)$ from STD.

${ }^{6}$ Statistically different $(P=0.032)$ from STD.

${ }^{7}$ Statistically different $(P=0.001)$ from STD.

first part of the study (sample set 1), 204 udder quarter milk samples were taken aseptically from 200 dairy cows in 41 Swedish dairy herds by trained extension service personnel. Only quarters from cows with subclinical mastitis were sampled. To qualify for the study, the cow composite milk SCC should have been $\geq 300,000$ cells/ $\mathrm{mL}$ at each of 3 consecutive monthly samplings before the sampling occasion. On the day of sampling, the udder should have normal consistency, and quarters having slight, moderate, or high California Mastitis Test (CMT) reaction were sampled. The samples were transported at ambient temperature to the laboratory on the day of sampling $(\mathrm{n}=122)$, or were sent by mail, reaching the laboratory the day after sampling $(\mathrm{n}=82)$.

Based on the results of sample set 1, the selection of herds and cows and sample handling methods were changed somewhat in the second part of the study. In sample set 2, dairy herds included should have been recently diagnosed with udder health problems caused by Staph. aureus infections. Trained personnel from the National Veterinary Institute (Uppsala, Sweden) took aseptic milk samples from all udder quarters of cows having at least one udder quarter that had been culture positive for Staph. aureus within the last 2 mo. Milk samples were also taken from all udder quarters of cows that, according to the farmer, occasionally had increased SCC during the last 2 mo or had slight swelling of an udder quarter or a few clots in the milk, but had normal udder consistency on the day of sampling. The samples were transported chilled to the laboratory on the same day. Sample set 2 consisted of 192 udder quarter samples from 49 cows on 7 farms. Four udder quarters were excluded from sampling, as they were nonlactating. Different combinations of methods were applied for sample set 2 subsets I and II, as specified in Table 1.
Upon arrival at the laboratory, one part of each milk sample was immediately frozen overnight at $-20^{\circ} \mathrm{C}$, and the rest of the sample was stored overnight at $+4^{\circ} \mathrm{C}$. All samples in sample sets 1 and 2 were further processed the next day.

\section{Processing Methods for Bacteriological Culturing}

In total, 8 sample processing methods were applied for sample sets 1 and 2, as specified in Table 1. The following methods were used: 1) standard (STD): culturing of $10 \mu \mathrm{L}$ of fresh milk without any pretreatment; 2) enrichment (ENR): $1 \mathrm{~mL}$ of fresh milk was added to an equal volume of nutrient broth (Oxoid, Basingstoke, UK) with $10 \%$ horse serum (SVA, Uppsala, Sweden) and incubated for $4 \mathrm{~h}$ at $37^{\circ} \mathrm{C}$ with gentle shaking, and $10 \mu \mathrm{L}$ of milk was cultured; 3) larger volume (VOL): culturing of $100 \mu \mathrm{L}$ of fresh milk without any pretreatment; 4) sedimentation (SED): $5 \mathrm{~mL}$ of fresh milk was centrifuged $(2,200 \times g, 20 \mathrm{~min})$, the fat and supernatant was removed, and $10 \mu \mathrm{L}$ of the sediment was cultured; 5) Mastistrip method (MS): described below; 6) freezing (FRZ): frozen milk samples were thawed at room temperature, and $10 \mu \mathrm{L}$ of milk was cultured; 7) freezing and incubation (FRZ+INC): frozen milk samples were thawed at room temperature, incubated (without any additives) for $18 \mathrm{~h}$ at $37^{\circ} \mathrm{C}$, and $10 \mu \mathrm{L}$ of milk was cultured; 8) incubation (INC): fresh milk was incubated (without any additives) at $37^{\circ} \mathrm{C}$ for $18 \mathrm{~h}$, and $10 \mu \mathrm{L}$ of milk was cultured.

When appropriate, the samples were mixed thoroughly before culturing on 5\% bovine blood agar (Oxoid) with $0.05 \%$ esculin (Merck, Darmstadt, Germany). The agar plates were incubated for 18 and $42 \mathrm{~h}$ at $37^{\circ} \mathrm{C}$, and growth or no growth of Staph. aureus was registered. In sample set 1 , the number of colony-forming units of 
Staph. aureus was also recorded as sparse (1-10 cfu/ plate), moderate $(11-50 \mathrm{cfu} /$ plate $)$ or abundant $(>50$ cfu/plate), for all methods except ENR and MS.

\section{The Mastistrip Method}

The Mastistrip technique (Nilsson, 1994; HonkanenBuzalski, 1995) has been used routinely for sampling and subsequent analyses of bacterial growth for more than a decade at the National Veterinary Institute in Sweden. The sampling device, Mastistrip (SVA, Uppsala, Sweden), consists of 4 projectable strips, each containing 2 filter paper discs, one for measurement of ATP (not used in this study) and one for bacteriological examination. The strips are protected by a plastic cassette, which contains silica gel for rapid drying of the discs after sampling. Normally, milk is directly squirted onto the discs when sampling the cow, but, in this experiment, the discs were inoculated immediately upon arrival of the milk sample to the laboratory by adding $100 \mu \mathrm{L}$ of milk to the disc for bacteriological examination. This volume is known to saturate the filter disc and is equal to the volume sampled cow-side. The cassettes were stored at room temperature overnight. Then, the discs were removed, and each one was placed in $0.5 \mathrm{~mL}$ of RPMI 1640 cell culture medium (SVA) in a test tube that was gently shaken for $10 \mathrm{~min}$ at room temperature. Thereafter, the samples were incubated for $18 \mathrm{~h}$ at $37^{\circ} \mathrm{C}$, and $50 \mu \mathrm{L}$ of the milk/medium mixture (corresponding to $10 \mu \mathrm{L}$ of milk) was cultured on blood agar as described above.

\section{Identification of Staph. aureus}

Growth of Staph. aureus was verified by colony appearance and the ability to produce $\alpha$ - or $\alpha$ - and $\beta$-hemolysis on bovine blood agar. Isolates producing only $\alpha$-hemolysis were confirmed by a positive tube coagulase test according to accredited methods (SS-EN ISO/IEC 17025; ISO, 2005). The coagulase test was read after 2,4 , and $18 \mathrm{~h}$. If a sample was positive at any of these time points, it was considered positive.

\section{Statistics}

The probability of identifying Staph. aureus in milk samples and the probability of different sample processing methods resulting in sparse, moderate, or abundant growth of Staph. aureus was compared statistically by Fisher's exact test (Statistica 6.0, StatSoft Inc., Tulsa, OK).

\section{RESULTS}

Studies were performed to identify milk samples positive for Staph. aureus after handling and culturing ac- cording to different processing methods. The number of Staph. aureus positive samples identified with at least one method was $40(20 \%), 20(37 \%)$, and $38(28 \%)$, in sample set 1 , sample set 2 (subset I), and sample set 2 (subset II), respectively (Table 1 ).

\section{Sample Set 1}

In this sample set, collected from udder quarters with slight, moderate, or high CMT reaction, 27 (68\%) of 40 Staph. aureus-positive samples were identified by all 6 methods tested. In 9 samples (22.5\%), Staph. aureus was isolated by only one method, evenly distributed among the methods tested. The STD method identified $78 \%$ of the samples (Table 1). The other methods did not differ significantly in their probability to detect Staph. aureus compared with the STD method. Abundant growth of Staph. aureus was observed more often when VOL was used than when STD was used. Freezing of milk (FRZ) before culturing did not have a significant effect on the number of colony-forming units (Table 2).

\section{Sample Set 2}

Samples for sample set 2 were collected with a slightly different approach than used for sample set 1 . In subset I, 7 (35\%) of 20 Staph. aureus-positive samples were identified by all 5 methods tested. Twelve isolates (60\%) were detected only using the method FRZ+INC. In total, 19 (95\%) of the Staph. aureus-positive samples were identified with this method, which is significantly $(P<0.001)$ more than with the STD method (Table 1). At the cow level, 7 (50\%) of 14 cows were Staph. aureus-positive when tested using the STD method, compared with 10 (71\%) of 14 cows tested using the FRZ+INC method.

In subset II, 19 (50\%) of 38 Staph. aureus-positive samples were identified with all 4 methods tested. Eleven $(29 \%)$ samples were positive only in one or both FRZ+INC and INC. The number of positive samples was significantly higher when using FRZ + INC $(P=$ $0.032)$ or INC $(P=0.001)$ compared with STD (Table 1). Using INC, the number of Staph. aureus-positive udder quarters increased by $50 \%$ compared with using STD. At the cow level, Staph. aureus-positive milk samples were found in 17 (49\%) of 35 cows when using the STD method, whereas 20 cows $(57 \%)$ and 22 cows (63\%) were positive with FRZ+INC and INC, respectively, an increase of 18 and $29 \%$, respectively.

When combining subsets I and II, 32 of $58(55 \%)$ milk samples were Staph. aureus-positive using STD compared with $30(52 \%)$ positive milk samples when using FRZ and $52(90 \%)$ positive milk samples when using FRZ+INC. The results obtained with FRZ+INC were significantly different $(P<0.001)$ from STD. 
Table 2. Numbers (\%) of Staphylococcus aureus-positive bovine udder quarter milk samples with sparse (1-10), moderate (11-50), and abundant (>50) growth of Staph. aureus (cfu per plate) using different sample processing methods ${ }^{1}$

\begin{tabular}{|c|c|c|c|c|}
\hline Method & $\begin{array}{c}\text { Staph. aureus } \\
\text { positive samples, } \\
\mathrm{n}(\%)\end{array}$ & $1-10 \mathrm{cfu}, \mathrm{n}(\%)$ & $11-50 \mathrm{cfu}, \mathrm{n}(\%)$ & $>50 \mathrm{cfu}, \mathrm{n}(\%)$ \\
\hline STD & $32(100)$ & $14(44)$ & $10(31)$ & $8(25)$ \\
\hline VOL & $31(100)$ & $4(13)^{2}$ & $11(35)$ & $16(52)^{3}$ \\
\hline SED & $32(100)$ & $8(25)$ & $9(28)$ & $15(47)$ \\
\hline FRZ & $29(100)$ & $10(34)$ & $10(34)$ & $9(32)$ \\
\hline
\end{tabular}

${ }^{1} \mathrm{STD}=$ standard method; VOL = larger volume method; SED = sedimentation method; FRZ = freezing method.

${ }^{2}$ Statistically different $(P=0.011)$ from the STD method.

${ }^{3}$ Statistically different $(P=0.039)$ from the STD method.

\section{DISCUSSION}

Accurate and easy-to-perform methods for routine bacteriological culturing of milk samples for identification of Staph. aureus-positive quarters and cows are essential for udder health control programs aiming at reducing the spread of Staph. aureus between cows within and between dairy herds. The results of the present study show that incubation of the milk sample at $37^{\circ} \mathrm{C}$ for $18 \mathrm{~h}$, with or without previous freezing of the sample before culturing, significantly improved the ability to isolate Staph. aureus. Using this incubation method, the number of Staph. aureus-positive udder quarters and cows increased 50 and 29\%, respectively, compared with using the standard method (direct culture of $10 \mu \mathrm{L}$ of milk).

We suggest that many samples with low numbers of Staph. aureus are not detected by the standard method, but can be detected by the improved method described and that the essential difference is the extra incubation step before culturing.

Samples identified only by the INC method had no or trace CMT reaction more often compared with samples detected by the standard method (our unpublished results). Samples with no or trace CMT reaction would not normally have been sent for bacteriological analysis by the practitioner, as the most common routine is to select quarters with a higher CMT reaction. Thus, udder quarters with no or trace CMT reaction should be considered as possible reservoirs for Staph. aureus, which could be of importance in tracing infected cows. However, further studies are needed to clarify if the bacteria identified in samples with low CMT reactions actually represent true IMI. The possibility of contamination from teat openings and skin should also be considered.

Among the other methods tested, several have been reported to increase the probability of isolating Staph. aureus in bovine milk. For instance, Zecconi et al. (1997) found more Staph. aureus-positive samples after centrifugation of the milk sample and culture of the sediment compared with direct culture of $0.01-\mathrm{mL}$ aliquots. Culturing an increased volume of milk has also been shown to increase the recovery rate of bacterial pathogens (Dinsmore et al., 1992). None of these findings could be confirmed in the present study, but both the VOL and SED procedures resulted in growth of higher numbers of Staph. aureus than the standard method.

Attempts to increase the sensitivity of detecting Staph. aureus have also been made by testing different enrichment procedures before bacteriological culturing with varying results (Thurmond et al., 1989; Sol et al., 2002; Yamagishi et al., 2007). In our study, neither enrichment of samples in nutrition broth nor processing by the Mastistrip method had any effect on the isolation of Staph. aureus. The positive effect of the incubation step without additives in the present study is probably because of the propagation of a few bacteria or just a refreshing needed before culturing. Milk seems to be an adequate incubation medium for this purpose and even if other bacteria present in milk also propagate, the results show an increased probability for isolating Staph. aureus. Testing Staph. aureus isolated by 4 different methods, including the incubation method, from the same milk samples by pulsed-field gel electrophoresis showed that all isolates were of the same pulsotype (unpublished results), indicating the propagation of a single pulsotype of Staph. aureus from each sample.

In the present study, overnight freezing did not increase the number of Staph. aureus-positive samples. This is in line with Bashandy and Heider (1979), Schukken et al. (1989), and Murdough et al. (1996), but in contrast to Villanueva et al. (1991), who isolated Staph. aureus more frequently when milk samples had been frozen for $23 \mathrm{~d}$. The positive effect of freezing has been suggested to be an effect of disrupted bacterial cell aggregates, increasing the number of colony-forming units per milliliter, or the release of phagocytized bacteria from lysed cells (Villanueva et al. 1991). In our study we found 
significantly more Staph. aureus-positive samples when freezing of milk samples was followed by an incubation step before culturing compared with the standard method, which is in line with Sol et al. (2002). But, as already mentioned, freezing before incubation did not improve the probability of finding Staph. aureus-positive samples compared with incubation only. A drawback with freezing of milk samples is that growth of other common udder pathogens may be reduced, as shown by Luedecke et al. (1972) and Schukken et al. (1989), when studying the long-term effects of freezing. Because the main goal of the present study was to find improved methods for culturing Staph. aureus in milk, the effects on other mastitis pathogens were not investigated.

Many new methods to demonstrate the presence of Staph. aureus in mastitic milk are based on the demonstration of specific DNA (Phuektes et al., 2003; Studer et al., 2008; Taponen et al., 2009). These methods are often evaluated by comparison with classical culturing methods and show high sensitivity and specificity. We suggest that the improved culturing method described in this paper may also be helpful in future evaluation of new methods.

\section{CONCLUSIONS}

Our results indicate an increased probability of detecting Staph. aureus in milk samples when a simple incubation step without additives is included before culturing. The improved method may be especially useful for detection of low concentrations of Staph. aureus and when screening herds for Staph. aureus. The effect of the incubation step on growth of other udder pathogens has not been investigated. Therefore, we suggest that the method should only be used for identification of Staph. aureus.

\section{ACKNOWLEDGMENTS}

The authors thank the Swedish Farmer's Foundation for Agricultural Research and the Swedish Research Council for Environment, Agricultural Sciences and Spatial Planning for financial support. We also thank Jelena Jovanovic and the personnel at the mastitis laboratory at the National Veterinary Institute (Uppsala, Sweden) for skilful technical assistance and Anna Aspan (National Veterinary Institute, Uppsala, Sweden) for valuable comments on the manuscript.

\section{REFERENCES}

Barkema, H. W., Y. H. Schukken, and R. N. Zadoks. 2006. Invited review: The role of cow, pathogen, and treatment regimen in the therapeutic success of bovine Staphylococcus aureus mastitis. J. Dairy Sci. 89:1877-1895.

Bashandy, E. Y., and L. E. Heider. 1979. The effect of freezing of milk samples on the cultural results. Zentralbl. Veterinarmed. B $26: 1-6$.
Daley, M. J., E. R. Oldham, T. J. Williams, and P. A. Coyle. 1991 Quantitative and qualitative properties of host polymorphonuclear cells during experimentally induced Staphylococcus aureus mastitis in cows. Am. J. Vet. Res. 52:474-479.

Dinsmore, R. P., P. B. English, R. N. Gonzalez, and P. M. Sears. 1992. Use of augmented cultural techniques in the diagnosis of the bacterial cause of clinical bovine mastitis. J. Dairy Sci. 75:27062712.

Graber, H. U., M. G. Casey, J. Naskova, A. Steiner, and W. Schaeren. 2007. Development of a highly sensitive and specific assay to detect Staphylococcus aureus in bovine mastitic milk. J. Dairy Sci. 90:4661-4669.

Honkanen-Buzalski, T. 1995. Sampling technique, transportation and history. Pages 111-114 in The Bovine Udder and Mastitis. M. Sandholm, T. Honkanen-Buzalski, L. Kaartinen and S. Pyörälä, ed. Gummerus Kirjapaino Oy, Jyväskulä, Finland.

Kossaibati, M. A., and R. J. Esslemont. 1997. The costs of production diseases in dairy herds in England. Vet. J. 154:41-51.

Luedecke, L. O., T. L. Forster, K. Williams, and J. K. Hillers. 1972. Effect of freezing and storage at $-20^{\circ} \mathrm{C}$ on survival of mastitis pathogens. J. Dairy Sci. 55:417-418.

Murdough, P. A., K. E. Deitz, and J. W. Pankey. 1996. Effects of freezing on the viability of nine pathogens from quarters with subclinical mastitis. J. Dairy Sci. 79:334-336.

Nilsson, L. 1994. Studies on diagnosis of mastitis according to a new method - MASTISTRIP. 1:104 and 2:35-37 in XVII Nordic Veterinary Congress, Reykjavik, Iceland. Icelandic Veterinary Association, Reykjavik.

Østergaard, S., M. G. Chagunda, N. C. Friggens, T. W. Bennedsgaard, and I. C. Klaas. 2005. A stochastic model simulating pathogenspecific mastitis control in a dairy herd. J. Dairy Sci. 88:42434257.

Phuektes, P., G. F. Browning, G. Anderson, and P. D. Mansell. 2003. Multiplex polymerase chain reaction as a mastitis screening test for Staphylococcus aureus, Streptococcus agalactiae, Streptococcus dysgalactiae and Streptococcus uberis in bulk milk samples. J. Dairy Res. 70:149-155.

Schukken, Y. H., J. A. H. Smit, F. J. Grommers, D. Vandegeer, and A. Brand. 1989. Effect of freezing on bacteriologic culturing of mastitis milk samples. J. Dairy Sci. 72:1900-1906.

Sears, P. M., B. S. Smith, P. B. English, S. Herer, and R. N. Gonzalez. 1990. Shedding pattern of Staphylococcus aureus from bovine intramammary infections. J. Dairy Sci. 73:2785-2789.

Sol, J., O. C. Sampimon, E. Hartman, and H. W. Barkema. 2002. Effect of preculture freezing and incubation on bacteriological isolation from subclinical mastitis samples. Vet. Microbiol. 85:241-249.

Studer, E., W. Schaeren, J. Naskova, H. Pfaeffli, T. Kaufmann, M. Kirchhofer, A. Steiner, and H. U. Graber. 2008. A longitudinal field study to evaluate the diagnostic properties of a quantitative real-time polymerase chain reaction-based assay to detect Staphylococcus aureus in milk. J. Dairy Sci. 91:1893-1902.

Swedish Dairy Association (Svensk Mjölk). 2008. Summary of cow control data from Swedish dairy cows. Djurhälsovård 2007/2008. Swedish Dairy Association, Stockholm.

Taponen, S., L. Salmikivi, H. Simojoki, M. T. Koskinen, and S. Pyörälä. 2009. Real-time polymerase chain reaction-based identification of bacteria in milk samples from bovine clinical mastitis with no growth in conventional culturing. J. Dairy Sci. 92:2610-2617.

Thurmond, M. C., J. W. Tyler, D. M. Luiz, C. A. Holmberg, and J. P. Picanso. 1989. The effect of pre-enrichment on recovery of Streptococcus agalactiae, Staphylococcus aureus and mycoplasma from bovine milk. Epidemiol. Infect. 103:465-474.

Villanueva, M. R., J. W. Tyler, and M. C. Thurmond. 1991. Recovery of Streptococcus agalactiae and Staphylococcus aureus from fresh and frozen bovine milk. J. Am. Vet. Med. Assoc. 198:1398-1400.

Yamagishi, N., Y. Jinkawa, K. Omoe, S. Makino, and K. Oboshi. 2007. Sensitive test for screening for Staphylococcus aureus in bovine mastitis by broth cultivation and PCR. Vet. Rec. 161:381-383.

Zecconi, A., R. Piccinini, A. Zepponi, and G. Ruffo. 1997. Recovery of Staphylococcus aureus from centrifuged quarter milk samples. J. Dairy Sci. 80:3058-3063. 